\title{
The Appreciation of Film: The Postwar Film Society Movement and Film Culture in Britain
}

Richard Lowell MacDonald

Exeter, University of Exeter Press, 2016

pp. 248, index, ill., bibliography, notes, $£ 65.00$ (cloth)

ISBN 9780859898881

MacDonald uses a sentence by film critic Paul Rotha to describe the importance of film societies and their role in promoting the appreciation of - 'Film societies owe their existence to groups of men and women who translate the unspoken need for study and discussion of the culture of cinema into practical action' (cited on p. 2). Unfortunately, as MacDonald writes, the importance of these amateur activities and enthusiasm has not been paid attention to or featured in the history of film culture in Britain. Therefore, MacDonald's book 'aims to recover a sense of the organisational vigour and pioneering role of the film societies in organised film study activity, critical writing and debate about film and the development of distinctive traditions of film programming' (p. 2). More importantly, MacDonald's historical research provides an alternative acknowledgement of these forgotten civic activities, and their contributions toward the intellectual and political engagements with the cinema that are normally absent in films studies. In a chronological order, each chapter not only highlights the significant events during a specific period of time that enriched the culture of film on a civic level, MacDonald also critically assesses these events, movements, and their impact on building the history of cinema culture in Britain.

In Chapter 1, MacDonald looks into the emergence of the film society movement in the late 1920s and its development in the 1930s. He evaluates two important motivations behind this pioneering effort: a desire for "better films", as well as a political desire to "raise workingclass consciousness through film'. Apart from presenting the details of different societies across cities with specific names of events people and archival materials, MacDonald also makes a very important observation about the value of these early film societies. Not only these lively film screening activities demonstrated an enthusiasm toward film art and culture in the public, there was also a sense of MacDonald calls the 'civic duty' from the enthusiasts. 'A film society was a private association for subscribing members but it articulated ideals and ambitions to shape opinion amongst the cinema public' (p. 16). This is the first time that many of the names of people and societies appear in an academic scholarship which, they certainly signal some new potentials for further individual research projects.

Chapter 2 focuses on the post-war transformation of the film society movement. As MacDonald points out, both the political and technological changes in the post-war period enabled the film society movement to become even more vibrant. Thanks to the birth of $16 \mathrm{~mm}$ projection equipment, which is smaller and more mobile, 'film societies became viable for smaller groups and in less populous cities and towns' (p. 41). While the bigger film society model that relies on membership subscription in the big cities continue, and the post-war period experienced a rise of some smaller film appreciation gatherings which led to a 'small audience economy'. This chapter thus pays close attention to 'the significance of changes in the technologies of projection used by societies'. It looks at how the new technology of $16 \mathrm{~mm}$ projection enables educational bodies to promote film appreciation as a topic of study, and more public activities organised by enthusiasts to promote film culture intellectually and critically. MacDonald also highlights the importance of the active viewing within the film society movement. The details about different film society activities and the activeness that these audience and promoters had during this period captured by MacDonald's careful historical survey, are the most convincible evidence to support that before the academicisation of film studies as a discipline, there was already a very lively and vibrant intellectual culture 
and environment around promoting, discussing and writing about the cinema. Furthermore, many educational bodies as well as societies from universities also participated in the movement to enrich the cinema culture in the UK. One argument made by MacDonald in this chapter is quite crucial to demonstrate the activeness and willingness of the activists in the film society movement, which is the voluntary membership subscription of most of these societies. MacDonald writes, 'membership of a film society implied that one's participation was voluntary rather than obligatory', [...] 'the lack of compulsion and its self-directed nature gave it a unique educational value' (p. 64).

Chapter 3 moves away from the focus on $16 \mathrm{~mm}$ projection and its implication on the development on smaller film societies, to 'the dissemination of non-specialist publications on film appreciation'. In the author's view, these publications also played a critical role in popularising the movement of film society. He focuses on discussing one example in particular, the 1944 publication Film by Roger Manvell under Penguin Books. MacDonald re-highlights the importance of this book, 'Rober Manvell and Film are now largely forgotten, but the book represents a missing chapter in the history of film education in the UK' (p. 66). Furthermore, MacDonald puts Manvell's book in contrast to Rudolf Arnheim's Film (1933). To use this comparison as a case studies, MacDonald argues that, 'Manvell's Film was an entirely new kind of publishing venture, a work on the art of film that consciously reached out to a broader social constituency than had been addressed by the serious film writing of the 1930s' (p. 68). MacDonald's reintroduction to Penguin Books' effort in popularising film appreciation opens many doors for our further studies. In fact, there are a series of books published under Penguin up until late 1960s which all devoted to a similar purpose, to popularise the new intellectual topic of film among the ordinaries with an accessible language. However, their contributions toward film appreciation and education have always been by passed or silenced, in particular after when film studies became a "proper" academic field.

Chapter 4 discusses around the topic about programming for film societies, and its 'relation to the institutions and practices that were in a position to influence the supply of films to the film society exhibitor' (p. 83). Film societies normally followed these types of programmes, 'current foreign films', 'revivals of outstanding films of the past', 'films illustrating the history of cinema and development of film art', and 'compilations from films that experimented in the way they presented ideas and action' (p. 83). As MacDonald illustrates in this chapter, programming for society is not only a simple task to select film screenings for members, such practice was also closely working with the Federation of Film Societies, The National Film Library, colleges and other public and private bodies at that time. More importantly, MacDonald highlights the educational values and responsibilities for the general public that enabled by these armature film societies.

Chapter 5 explores the internationalism in the post-war film society movement and its relationship between 'a range of newly formed institutions with avowedly internationalist commitments engaged in film production, distribution or exhibition' (p. 103). There are two main focuses in this chapter. It first looks at Britain's first international film festival established by the Edinburg Film Guild in 1947, by outlining an alternative history about its relationship with UNESCO through promoting the festival's support and enthusiasm in documentary. The second focus is the distributor Contemporary Films, a company which has been promoting foreign language films in Britain since 1951. MacDonald summaries the significance of this company as: 'Contemporary offered the most internationally diverse film library available to film societies and specialists cinemas' (p. 104).

As the history moves forward, we have learnt about the establishment of the film society movement, its popularisation, film festival and film programming. Chapter 6 focuses on a new emerging activity that was also actively connected to the movement - film criticism. It looks at one particular publication in depth, Film News. This important publication, in MacDonald's 
words, 'documents shifting taste and critical judgement within the film society movement of the 1950s and early 1960s' (p. 134). Film criticism represented by Film News not only 'mediated the discovery of new films, guiding film society organisers in programming choice', but it also contributed to the film practices for new cinemas (p. 134). Overall, this chapter gives an insight toward the active interactions between film critics and the film society movement, as well as with the new emerging alternative auteur film practice as a response to Hollywood. As an additional bonus, this chapter also captures a very important debate on what the state of film criticism should be during the 1950s. This debate is still invaluable to reflect on our current thinking about film scholarship and the studies of cinema in general.

The final chapter looks at the transition from the voluntary, civic film society movement to the institutionalisation of film studies on a university level. One of the main points that MacDonald has been trying to demonstrate is the educational value up until this point, MacDonald has already provided many examples to demonstrate this historical fact. During the 1950s, the film society movement took up this educational responsibility even more seriously. In addition, film societies began to collaborate with university extra-mural departments in the following decade. MacDonald focuses on two contradictory attempts in this transitional period. One part focuses on the relationship between the film movement society and the introduction of film appreciation as a curriculum, the other part discusses in depth about the shift that The Popular Arts introduces to film education which proposes an opposite direction to forward. As well as being a historical survey, in comparison to the rest of the chapters, Chapter 7 is the most theoretical part of the book, as it later extends to critically reflect on the institutional intervention by Screen during the early 1970s. From a voluntary collective movement of appreciation, the study of film for the first time became a 'specialised jargon distinct from ordinary language'. Despite the rich history of the previous film culture and activities, the heavy influence from this institutional shift is still present in our research environment nowadays. Many have already reflected on the intervention led by Screen in film studies elsewhere; however, very few have provided a better and more detailed context to support such a reflection as MacDonald has done.

Certainly, one monograph cannot include all the lively cinematic activities throughout the history in Britain. Two major influences this book is able to inspire our thinking about the studies of cinema and its culture: 1) the research into the history of film appreciation and the studies of cinema are full of potentials and undiscovered territories, a similar project can be done but perhaps with a more local or individual focused case study; 2) we must also use these historical research projects on film culture and activism in film promotion as a critical medium, and to think about how they can help us to reflect on the current state of film studies as a discipline, its dominant rhetoric, limitations, ignorance and potentials for future developments. Film Appreciation sets out a very meaningful foundation for scholars to investigate and explore the rich cinema history and culture in the UK. Each name of the society and publication that is mentioned in this book deserves a separate historical research as one specific project. Furthermore, each of this potential in depth research in the future will by all mean help us better appreciate and acknowledge what people have done in the past to promote and evaluate film culture. We can learn from these historical lessons, to avoid the mistakes and to continue with the good practices. There are still a lot of works to be done in our research, if we care and appreciate how the audience, activists and intellectuals have been interacting with cinema throughout the history. The author finally concludes:

If appreciation is understood as a collectively articulated concern with facilitating the broadest social participation in discussing what film images should be valued and why, then the question the post-war film society movement poses to the radically changed circumstances of the present is simply this: how is appreciation of these film images fostered now? (p. 202) 
Film Appreciation is a critical history on the development of film culture and education during the post-war Britain. It is not only a historical investigation but also with a strong sociological interest. MacDonald and his thoughtful monograph, with patience and sincerity, invite us to acknowledge the appreciation of film among the ordinaries, and their important efforts in shaping the film culture we enjoy today.

Hiu M. Chan Birmingham City University (C) 2016, Birmingham City University Hiu-Man.Chan@bcu.ac.uk 